\section{Investigation of similarities and differences between Dance Tourism markets: the case of Patras, Greece}

Zouni, Georgia ${ }^{a}$; Karlis, Aggelos ${ }^{\mathrm{b}}$; Georgaki, Ioannac

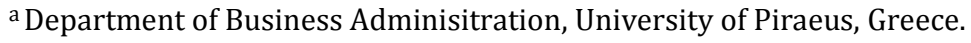
gzouni@gmail.com

b Hellenic Open University, Greece. aggelkara@yahoo.gr

c Heriot Watt University, United Kingdom. Ioannag33@hotmail.com

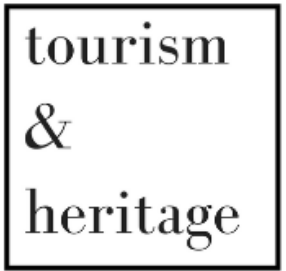

J O U R N A L

\section{ARTICLE INFO}

\section{Article history:}

Received 20 February 2019

Accepted 21 May 2019

Published 27 June 2019

\section{Keywords:}

Dance Tourism; Cultural Tourism; Market Research; Market Segmentation; Patras; Greece

\section{ABSTRACT}

In every corner of the world, we observe that tourism destinations, having understood the importance of dance events, try to increase the presentation of such dance events, with the aim to attract and entertain tourists. Dance tourism constitutes a part of cultural tourism since, through that, opportunities for cultural experience are provided to tourists. The main aim of the present research is the investigation of the similarities and differences between Greek and Russian dance tourists towards dance tourism in a tourism destination (Patras, Greece), regarding: (a) the Demographic characteristics, (b) attitude towards dance tourism, and (c) attitude towards Patras as a dance tourism destination. Results show that younger individuals, mainly women, that are single, of high educational level, private-sector employees mainly, and of medium income are interested in dance tourism. Moreover, several interesting results found regarding attitude towards dance tourism, and attitude towards dance tourism destinations. The contribution of this study is twofold. For both For academia, this research might deepen the understanding of dance tourism travellers and its impact on destinations products formulation. For practitioners, this kind of approach might provide new and strategically important knowledge about attracting dance tourists. 


\section{INTRODUCTION}

Cultural tourism through folk tradition, museums, music, dance and arts constitutes a significant element which gives particular value to the tourism product and it can inspire millions of tourists to visit new destinations. Dance undoubtedly occupies a prominent position in the society throughout the history of human culture. It is a timeless and universal phenomenon. It constitutes a means of communication and it is the mirror of the life of a human, since it is the means through which $\mathrm{s} /$ he expresses his/her feelings at every moment of his/her life. The present study is concerned with the investigation of the possibility to develop dance tourism at the municipality of Patras, a historic city in southern Greece. In particular, the aim of the research is to investigate the similarities and differences between two target markets, Greek and Russian dance tourists in relation to: (a) the Demographic characteristics, (b) attitude towards dance tourism, and (c) attitude towards Patras as a dance tourism destination.

\section{LITERATURE REVIEW}

\subsection{Dance as a cultural asset}

Dance belongs to the intangible cultural heritage of humanity. It includes traditions and expressions of uncountable groups and communities which have been imparted from generation to generation. UNESCO (2003) recognises the importance of intangible cultural heritage. Notably, intangible cultural heritage is defined as the language, the arts (such as music and dance), the crafts, the traditions, the morals and the customs, as defined in the text of the contract of the General Conference of UNESCO in 2003 for the protection of intangible cultural heritage. Intangible cultural heritage encompasses the skills and knowledge that are imparted from generation to generation in a community. However, these skills and knowledge interact with the environment of the place and the history of the communities. In the articles of the contract, an attempt is made to protect the intangible cultural heritage (UNWTO/UNESCO World Conference, 2016). Hesiod mentions that dance is the divine gift of Terpsichore (one of the nine Muses- Muse and protector of dance and of dramatic choric). The person who has sorrow and sadness in his soul dances and by that succeeds to forget the negative thoughts and his/her problems. Over the centuries many people have devoted their lives to this type of art. Some of them stood out and their contribution was priceless, thus, dance was given prominence; it evolved from a form of communication to a phenomenon of art. That is to say, dance constituted an element of the culture, which was a creation of a group of people in a specific era, through which the needs of the particular group were expressed. Since over time social needs were changing, dance did not remain stable either but it was changing as well, thus constituting a dynamic cultural phenomenon (Prantzidis, 2005, p.12-13). 


\subsection{Dance Tourism}

Whether viewed as an expression of high or low culture, dance has long been a tourist attraction (Wall \& Xie, 2005, p.1). Dance Tourism through folk tradition, museums, music, dance and arts constitutes a significant element that gives particular value to the tourism product and it can inspire millions of tourists to visit new destinations. Dance tourism is a part of cultural tourism since, through that, opportunities for cultural experience are provided to tourists. It is addressed to tourists who wish to live a special experience through their participation in dance events at the area of their place of destination. Dance tourism is expressed either with the active participation of tourists in events or simply with their attendance at various dance events. The former refers to the dance participation in various social events, such as celebrations, fairs and their participation in dance training seminars. During these events, there is active participation of tourists. The latter is concerned with the attendance at various dance events, such dance festivals. At these events, there is no active participation of tourists and there is distance between the dancers and the tourism audience (Kringelbach \& Skinner, 2012).

The main motivation for a tourist who travels to a place to participate in dance events is obviously dance. That is to say, they are tourists whose main motivations are their either active or passive participation in dance events. Thus, the incentives of tourists who travel to a place for dance, should be explored by investigating their preferences to participate in dance events such as various events, dance festivals and dance seminars, regardless of their active or passive participation. Many researchers argue that the attendance of an individual at an event is connected as much with the motivation of the free time as with the tourism motivations. The aim of many studies was based on the reasons why an individual chooses to attend an event, the satisfaction that the individual receives from it and the connection of the motivations with their particular characteristics (Skoultsos, 2014).

Getz (1989) found that the four basic categories of needs (physical, cultural, interpersonal, recognition) are satisfied through the attendance at an event. Physical needs are satisfied by the participation to competing events or through the relaxation from the participation in a festival. Cultural needs are met with the contact with the culture of the place, with the participation in local celebrations at dance or music festivals. Interpersonal needs are satisfied by the communication with the audience of the festival. Finally, the need of recognition is met with the participation in activities that boost self-confidence (Getz, 1989).

Apart from the satisfaction of these needs, Getz supported that there are also benefits from the experience of participation at an event, which the visitor enjoys. These benefits distinguish the specific events from the permanent attractions. The benefits are the following: (a) the sense of belonging to a team; The sense of enjoyment of a common experience with other people constitutes a basic motivation of free time and of travel, (b) the authenticity; The benefits are based on the acquisition of authentic experiences from a place, (c) the enjoyment of the rituals of the events; The attendance of events which include traditional customs of a society gives to spectators the impression that sacred moments from the inhabitants' life are presented, (d) expectation for entertainment. Every visitor expects to have fun with his/her participation in events 
where there is a joyful atmosphere, and (e) the enjoyment of the spectacle. It is the expectation that the visitor has to attend something unique.

Getz (1991) connected these individual needs with the tourism motivations that the individual has and the benefits that $\mathrm{s} / \mathrm{he}$ expects to gain from the experience of participating in an event, suggesting three categories of basic needs: physical, interpersonal or social, and personal. His taxonomy was influenced by Maslow's (1943) hierarchy, but was adapted to embrace other suggested classifications (Crompton \& McKay, 1997). Scott (1995) conducted a research on three city festivals in the area of Ohio and he ended up in six factors: the reaction towards routine, the stimulation, the appreciation of nature, the sociability, the family solidarity and the curiosity. He also supported that the differentiation level of the motivations at the three festivals was due to the different theme that they had. Thus, he found that incentives are differentiated according to the type of festival.

Schneider and Backman (1996) at a study of the cultural festival of Jordan found the following incentives: escape, stimulation, family solidarity- socialisation, sociability- free time and characteristics of the festival. By comparing the results of the research with equivalent studies conducted in North America they found that regardless of the cultural differences of these countries the incentives were the same.

Nicholson and Pearce (2001) conducted studies on motivations at various festivals and events and they discovered that the particular characteristics of each event/festival influence also the motivations of visitors.

A research was conducted in 2006 by McCleary, Weaver and Meng on nine dance events, in five different areas of the United States of America, for the factors of motivations which lead Americans to take part in dance activities. Six motivations were established, " escape and relaxation», «sociability», «originality», «dance learning- improvement of dance skills», «enjoyment» and «excitement». From the same study it is also apparent that the majority of those who wished to attend at dance events were middle-aged, of high educational and income level.

In addition, a study that was addressed to the Andong Mask Dance Festival indicated that satisfaction had a close relationship to loyalty (Lee, Kyle, \& Scott, 2008). This insinuates that satisfaction from dance festivals has an impact on revisit intention.

Finally, a recent ethnographic study of Suharji (2017) had as an aim to describe the responds and cultural practice of Bedhaya Bedhah Madiun dance. The study showed that tourism stimulates significantly such audience.

\subsubsection{Dance Festival internationally and in Greece}

Internationally, there are examples from countries which use different dance events to attract tourists.

From a study on tourists' preferences for entertainment which took place in five cities of the area of Istria of Croatia, it is observed that there is an intense interest of tourists to participate in artistic events such as evenings with dance and live music (Tezak, Saftic, \& Sergo, 2011). In Ireland also there is an important correlation between dance and tourism. This relationship is important for the configuration of the cultural heritage of 
Ireland. This growing interest of tourists for dance has a as a result the increase of dance performances that take place for tourists. The growing popularity of national and traditional dances of Ireland constituted a unique expression of its culture (Foley, 2018). Dance constituted a part of the tourism product of Ireland since through those tourists have fun and relax, and it offers them a chance to participate in the local culture (Cronin \& O'Connor, 2003). The tribe Embera, in the community of Parara Puru, which is situated near the city of Panama, has converted the various dance religious ceremonies to a dance event for tourists. Therefore, through dance tourism, it has achieved worldwide projection of its ethnicity, and also it has managed to sensitize its inhabitants to engage with their culture (Kringelbach \& Skinner, 2012). Dances like Flamenco in Seville and the Tango in Buenos Aires, which have made their appearance in the $19^{\text {th }}$ century as a form of art, influence tourism in these cities. Through these dances and their touristic utilization, it is seen that the dances constituted the means with which these cities were projected as tourism destinations, and also the dances contributed to the final configuration of their tourism image (Thimm, 2014).

Daniel in 1996 mentioned that dance in Cuba can help tourists to escape from their everyday life and to gain a new experience. This, however, requires the active participation of tourists in dance; not being simple spectators. Many of the dance performances that are organized are commercialized. However, they manage to keep the authenticity of their traditions (Daniel, 1996). Cuban dancers instruct tourists to dance mostly the Salsa dance, through various seminars. In addition, evenings are organized where tourists can practice the dance they learned. Therefore, many packages for dance learning have been created which are addressed to tourists (Cuban Cultural Travel, 2019).

Another recent research, which was concerned with first-time and returning electronic dance festival attendees at the Daisy Carnival in Las Vegas, indicates that the changes from this experience are favourable and long-lasting (Little, Burger, \& Croucher, 2018).

Moreover, the past years, a great importance is given to the promotion of traditional dances in Greece as a motivation for cultural tourism (Filippou, et al., 2010). The local society has understood the positive influence of dance in tourism and thus, it organizes many dance festivals which include the presentation of traditional and modern dances. In addition, in the context of many customs, several events take place which include traditional dances.

In Greece, in the field of dance and music, the oldest organization of dance festivals is the Folklore Festival of Lefkada, which commenced in 1962. Until today, with the participation of a great number of dancers, singers and musicians, it has managed to be widely recognized in Greece and internationally and to attract many spectators and tourists.

In the city of Kalamata, the International Dance Festival takes place from 1995 with great success. Every July for 10 days, the festival is the only attraction for visitors from Greece and abroad. The festival also includes educational seminars and lectures which are addressed to dance students and professionals.

Finally, a recent study of Georgoula and Terkenli (2018) shows an analysis of two wellknown international arts festivals visitors' motives and profile characteristics, in two medium-sized Greek cities: the Kalamata International Dance Festival (KIDF) and the 
Drama International Short Film Festival (DISFF). Even though the two festivals were similar in terms of the organization and the aims, the focus of the analysis was the differentiation of attendance motives along with the visitors' characteristics for each of these events. As stated by the authors, "arts festivals-goers do not appear to constitute a single homogeneous market; rather, each event appears to attract different audiences for different reasons" (Georgoula \& Terkenli, 2018, p.187).

For the first time in 2016, the largest and most competitive dance festival was organized in Thessaloniki including Latin and modern types of dance with participation from 33 countries and 1500 dancers. The aim was to highlight the sports dimension of dance. In the context of the festival, dance seminars as well as two big parties took place.

Finally, the biggest Greek Folklore Festival takes place in Toronto of Canada. It is the largest street festival. Even though in the beginning it was aiming to the projection of Greek cuisine, over time it has become multicultural and it includes tasting events, presentations of Greek dances and music. It has gained much acceptance since it manages to attract a large number of visitors.

\section{RESEARCH METHODOLOGY}

In line with the above discussion, the main aim of the present research is to investigate the similarities and differences between two target markets, Greek and Russian dance tourists in relation to: (a) the Demographic characteristics, (b) attitude towards dance tourism, and (c) attitude towards Patras as a dance tourism destination. In order to investigate these aspects, a primary research was conducted to prospective tourists. More particularly, the following research information was investigated: a) the profile of tourists who prefer dance tourism, b) their attitude regarding the travels they do for dance reasons; that is to say, if they prefer to participate actively or simply, for which kind of events they travel to participate, from where they get information about them etc., and c) the evaluation of the municipality of Patras as a dance tourism destination, that is to say, tourists' satisfaction for the elements that structure the product or the services as well as their opinion for the dance events that take part in the municipality. The selection of the sampling was random and as representative of the total population as possible. The sample was selected by members of dance cultural associations, and private dance schools, that is to say, by institutions where people that participate in them are involved in dance activities. It is considered that the selected sample is the most suitable for the investigation of the information that we wish to gain. The time period of this research was two months, between May and June 2016. The method used was primary quantitative research through the use of a structured questionnaire, which was distributed both through the Internet (email and social media websites) and conducted in many areas of the Greek territory as well as of the Russian territory. The questionnaire questions were formulated in a way that they were clear and understandable to the respondents, ranging from closed-ended and open-ended questions to multiple choice questions, and Likert scale questions (agreement, importance, rating scale). The questionnaires were translated, apart from the Greek language, into Russian, so that tourists of this market could be included in this research. 
The number of the answered and usable questionnaires was 258. After the collection of the necessary sample of the questionnaires, their analysis followed. The data were coded and entered into SPSS 22.

\section{RESULTS}

The sample of the present research consists of 258 individuals in total. Regarding the gender of the total sample, women prevail with a percentage of $65,5 \%$ while men who participated in the research constitute the $34,5 \%$. The age distribution of the sample is the following: at the age group 26-35 the larger percentage is observed with $43,8 \%$, then the age group of people below 25 years old follows with $25,2 \%$ and then third is the age group 36-45 with 19,0\%. From the geographical distribution of the sample it arises that $79,9 \%$ are residents of Greece and the rest $22,1 \%$ are residents of Russia. As regards the educational level of the respondents' sample, the majority are graduates of Higher (AEI) or Technical (TEI) University with 52,3\%, while High School graduates follow with $35,3 \%$. Moreover, concerning the income of the sample, the largest percentage is observed at the scale $10.000,01 €-20.000 €$ with $44,2 \%$. Figure 1 summarises the sample demographic characteristics.

\begin{tabular}{|l|l|l|}
\hline Sex & & \\
\hline Men & 89 & $34,5 \%$ \\
\hline Women & 169 & $65,5 \%$ \\
\hline Sample Total & 258 & $100 \%$ \\
\hline Age & & \\
\hline Below 25 years old & 65 & $25,2 \%$ \\
\hline $26-35$ years old & 113 & $43,8 \%$ \\
\hline $36-45$ years old & 49 & $19,0 \%$ \\
\hline $46-55$ years old & 22 & $8,5 \%$ \\
\hline $56-65$ years old & 9 & $3,5 \%$ \\
\hline Above 65 years old & 0 & $0 \%$ \\
\hline Sample Total & 258 & $100 \%$ \\
\hline Country of permanent residence & & \\
\hline Greece & 201 & $77,9 \%$ \\
\hline Russia & 57 & $22,1 \%$ \\
\hline Sample Total & 258 & $100 \%$ \\
\hline Cities of permanent residence & & \\
\hline Athens & 76 & $29,5 \%$ \\
\hline Moscow & 39 & $15,1 \%$ \\
\hline Thessaloniki & 24 & $9,3 \%$ \\
\hline Trikala & 14 & $5,4 \%$ \\
\hline Corfu & 12 & $4,7 \%$ \\
\hline Kozani & 11 & $4,2 \%$ \\
\hline Saint Petersburg & 10 & $3,8 \%$ \\
\hline Other cities in Greece & 64 & $24,8 \%$ \\
\hline Other cities in Russia & 8 & $3,2 \%$ \\
\hline Sample Total & 258 & $100 \%$ \\
\hline & & \\
\hline
\end{tabular}




\begin{tabular}{|l|l|l|}
\hline Family Status & & \\
\hline Single & 148 & $57,3 \%$ \\
\hline Married & 60 & $23,3 \%$ \\
\hline Family with children & 49 & $19,0 \%$ \\
\hline Divorced & 0 & $0 \%$ \\
\hline Widow(er) & 1 & $0,4 \%$ \\
\hline Sample Total & 258 & $100 \%$ \\
\hline Educational Level & & \\
\hline Primary School Graduate & 0 & $0 \%$ \\
\hline Junior High School Graduate & 2 & $0,8 \%$ \\
\hline High School Graduate & 91 & $35,3 \%$ \\
\hline $\begin{array}{l}\text { Graduate of Higher (AEI) or Technical } \\
\text { (TEI) University }\end{array}$ & 135 & $52,3 \%$ \\
\hline Master's Degree Holder & 28 & \\
\hline PhD Holder & 2 & $10,8 \%$ \\
\hline Sample Total & 258 & $0.8 \%$ \\
\hline Average annual income & & $100 \%$ \\
\hline $0,00-10.000 €$ & 110 & \\
\hline $10.000,01 €-20.000 €$ & 114 & $42,6 \%$ \\
\hline $20.000,01 €-30.000 €$ & 28 & $44,2 \%$ \\
\hline $30.000,01 €-40.000 €$ & 5 & $10,9 \%$ \\
\hline $40.000,01 €$ and above & 1 & $1,9 \%$ \\
\hline Sample Total & 258 & $0,4 \%$ \\
\hline Occupation & & $100 \%$ \\
\hline Private-Sector employee & 120 & \\
\hline Civil Servant & 32 & $46,5 \%$ \\
\hline Self-employed & 55 & $12,4 \%$ \\
\hline Technician & 6 & $21,3 \%$ \\
\hline Rentier & 3 & $2,3 \%$ \\
\hline University Student & 40 & $1,2 \%$ \\
\hline Unemployed & 8 & $11,6 \%$ \\
\hline Housekeeper & 258 & $1,6 \%$ \\
\hline Sample Total & $3,1 \%$ \\
\hline & $100 \%$ \\
\hline
\end{tabular}

Figure 1. Sample demographic characteristics. Source: Own elaboration (2019).

\subsection{Similarities and differences of Greek and Russian dance tourists towards dance tourism in Patras}

In order to be able to discover some deviations on the main variables of the univariate analysis, the bivariate data analysis is necessary. At the bivariate analysis and with the help of cross-tabulation tables of SPSS, the two markets of Greece and Russia were separated, presenting detailed data on these two groups with regard to the variables of the questionnaire. Then, with the help of T-test, a statistical test of the deviations of the averages of both groups followed, assuming $\mathrm{P}>0,05$ as statistical significance.

The general hypothesis of the study is:

Ho: $\quad$ there is no difference between Greek and Russian dance tourists towards dance tourism in Patras, regarding: 
(a) the Demographic characteristics,

(b) attitude towards dance tourism, and

(c) attitude towards Patras as a dance tourism destination

T-tests and chi square tests were performed to evaluate the difference in means between the two samples- Greeks and Russians (Ho).

\subsubsection{Similarities and differences regarding the Demographic characteristics}

Regarding the gender, it is observed that there is significant statistical differentiation (2tailed $\rho=0,001)$; the average of the values of the group from Greece is higher $(\mathrm{M}=$ 1,71 , st. dev. $=0,454$ ) as compared with the average of the values of the group from Russia. This means that the participation of women from Greece is proportionally higher in percentage as compared with women from Russia.

Concerning the age, it is observed that there is significant statistical differentiation (2tailed $\rho=0,000)$; the average of the values of the group from Greece is higher $(\mathrm{M}=$ 2,32 , st.dev. $=1,077$ ) as compared with the average of the values of the group from Russia. This means that the average of age of the group from Greece is higher as compared with the equivalent of the group from Russia.

Concerning the marital status, it is observed that there is significant statistical differentiation (2tailed $\rho=0,015$ ); the average of the values of the group from Russia is higher $(M=1,86$, st.dev. $=0,895)$ as compared with the average of the values of the group from Greece. This means that Greeks are single regarding their family status in a proportionately larger percentage than the Russians.

Regarding the educational level, it is observed that there is significant statistical differentiation (2tailed $\rho=0,008$ ); the average of the values of the group from Russia is higher $(M=3,96$, st.dev. $=0,865)$ as compared with the average of the values of the group from Greece. This means that Russians have a higher educational level in relation to Greeks.

Concerning the annual personal income, it is observed that there is significant statistical differentiation (2tailed $\rho=0,000$ ); the average of the values of the group from Russia is higher $(M=2,16$, st.dev. $=0,978)$ as compared with the average of the values of the group from Greece. This means that Russians have higher income level in relation to Greeks.

Finally, with regard to the profession, no statistical significance was observed between two countries, with both samples answering that they are mainly private sector employees.

\subsubsection{Similarities and differences regarding the attitude towards dance tourism}

Concerning the reasons of travel (e.g. escape and relaxation, socialisation, originality, excitement), there is no significant statistical differentiation between the two countries. On the contrary, significant statistical significance $(2$ tailed $\rho=0,000)$ was observed at the question that concerns whether they travelled for dance reasons within the past 18 months; the average of the values of Russians is higher $(M=1,65$, st.dev. $=0,481)$ in relation to the average of the values of the group from Greece. This means that Russians tend towards the no at a proportionately larger percentage than Greeks. 
When asked about the main aim of travel (e.g., aim to dance, attend or both), results showed a significant statistical significance $(2$ tailed $\rho=0,000)$ between the two sample; the average of the values of Russians is higher $(M=2,21$, st.dev. $=0,986)$ in relation to the average of the values of the group from Greece $(M=1,48)$. That is to say, Greeks during these travels prefer to dance while Russians prefer to do both.

At the question that concerns with whom they prefer to travel, an important statistical differentiation is observed (2tailed $\rho=0,000$ ); the average of the values of Greeks is higher $(M=4,15$, st.dev. $=1,314)$ in relation to the average of the values of the Russian group $(M=3,18)$. That is to say, Greeks tend to travel with friends. Of course, Russians also prefer friends but it is observed that there are other important options for them, such as to travel with their partner.

In relation to the reasons of factors that encourage them to travel for a dance event, in spite of the observed important statistical differentiation between two variables in the two countries, this does not change the sequence of the choice of factors. It is confirmed that for both countries, escape and relaxation is the $1^{\text {st }}$ factor, dance learning/improvement of dance skills is the $2^{\text {nd }}$ factor and enjoyment of the dance event is the $3^{\text {rd }}$ factor of motivation.

Additionally, the choice of a destination depends on the provision of information for it, despite the fact that the differentiation is statistically significant ( 2 tailed $\rho=0,013$ ), the average of Greeks and of Russians is above 4. This means that the respondents from both countries consider important the level of information for the choice of a destination, and mainly via online sources.

Moreover, when asked about their preferred season for dance tourism, it is observed that there is an important statistical differentiation $(2$ tailed $\rho=0,032)$ for the variable other countries. What needs to be mentioned is that Greeks prefer to travel to attend a dance event in other countries, firstly, in spring and then in summer, while Russians, firstly, in spring and then in autumn.

A final question about travel behaviour was if they prefer to cooperate with travel agencies or tour operators for their travels. It is discovered that there is an important statistical differentiation ( 2 tailed $\rho=0,000$ ). Indeed, it is shown that Russians prefer in a larger percentage to cooperate with travel agencies or tour operators, while Greeks do not.

\subsubsection{Similarities and Differences regarding attitude towards Patras as a dance tourism destination}

It is observed that there is not important statistical difference between the two countries at the questions for the variables: cultural events, local market; for the variables: magazine advertisement, newspaper advertisement, advertisement in a tourism brochure, opinion of friends and family, the internet, social media and tourism exhibitions; for the variables: to be more of them in quantity, to give you the opportunity to participate actively, to give the opportunity for fun and entertainment and to present unique dance events (Ho).

Regarding past experience, respondents were asked if they have visited the Municipality of Patras in the past, and it is discovered that there is an important statistical differentiation ( 2 tailed $\rho=0,000$ ). Indeed, Greeks have a lower average $M=1,11$ in 
relation to $M=1,42$ from Russians. This means that there is a bigger percentage of Greeks that have visited the Municipality of Patras in relation to the respondents from Russians. By comparing the averages, it is observed that Russians stated that they were more fulfilled than Greeks.

In terms of 'value for money' aspects of the destination, it is discovered that there is an important statistical differentiation (2 tailed $\rho=0,000$ ). Indeed, Greeks have a lower average $M=3,08$ in relation to $M=4,27$ from Russians. This means that Greeks consider the level of prices as lower than the respondents from Russia.

When asked about the most important aim of their visit apart from dance, results showed that for Greeks the variable of attending cultural events is the $1^{\text {st }}$ option, the $2^{\text {nd }}$ option is the relaxation and recreation and $3^{\text {rd }}$ option the visit to archaeological sites and museums, while for Russians the $1^{\text {st }}$ option is participating in alternative tourism, the $2^{\text {nd }}$ option is for relaxation and recreation and the 3rd option is for summer vacation and swimming ( 2 tailed $\rho=0,000$ ).

At the question that concerns the way they choose to make a reservation, it is observed that there is an important statistical differentiation ( 2 tailed $\rho=0,000)$. Greeks choose to make a reservation to a greater extent online, while Russian choose also online with the biggest percentage of preference, but the variable through travel agency comes as the second reason at their preferences and it has a significant percentage, as well.

At the question that concerns the elements that dance events should have in order to develop dance tourism in the future, there is an important statistical differentiation at the variables:

(a) to give you the opportunity to live an authentic experience ( 2 tailed $\rho=0,000$ ). The average of Greeks is $M=3,59$ and of Russians is $M=4,47$. This means that Russians consider this element as more important to be included in dance events than Greeks do.

(b) To show the customs and traditions of the place (2 tailed $\rho=0,000$ ). The average of Greeks is $M=3,67$ and of Russians is $M=4,35$. This means that Russians consider this element as more important to be included in dance events than Greeks do.

(c) To give the opportunity of socialization and group enjoyment (2 tailed $\rho=$ 0,000 ). The average of Greeks is $M=4,05$ and of Russians is $M=4,40$. This means that Russians consider this element as more important to be included in dance events than Greeks do.

Figure 2 summarises the Assessment of the Municipality of Patras as a dance tourism destination by the two samples.

\begin{tabular}{|l|l|l|l|}
\hline Variables Q20 & 2 tailed $\boldsymbol{\rho}$ & Average of Greeks & Average of Russians \\
\hline Natural Environment & 0,000 & 2,70 & 4,41 \\
\hline Cultural Resources & 0,000 & 3,49 & 4,17 \\
\hline $\begin{array}{l}\text { Opportunities for } \\
\text { Entertainment }\end{array}$ & 0,006 & 4,43 & 4,00 \\
\hline Opportunities for & 0,000 & 2,29 & 3,92 \\
\hline
\end{tabular}




\begin{tabular}{|l|l|l|l|}
\hline alternative activities & & & \\
\hline Catering facilities & 0,002 & 3,60 & 4,00 \\
\hline Quality of lodgings & 0,000 & 3,13 & 3,94 \\
\hline $\begin{array}{l}\text { Accessibility of } \\
\text { destination }\end{array}$ & 0,000 & 2,94 & 4,03 \\
\hline Means of Transport & 0,000 & 2,56 & 3,89 \\
\hline Cleanliness & 0,000 & 2,79 & 4,14 \\
\hline Friendliness of locals & 0,000 & 3,54 & 4,28 \\
\hline Security & 0,000 & 3,67 & 4,44 \\
\hline Local Food for & 0,000 & 3,40 & 3,94 \\
\hline Infrastructure & 0,000 & 3,19 & 3,77 \\
\hline $\begin{array}{l}\text { Information } \\
\text { tourism activities }\end{array}$ & 0,000 & 2,32 & 3,79 \\
\hline
\end{tabular}

Figure 2. Assessment of the Municipality of Patras as a dance tourism destination. Source: Own elaboration (2019).

\section{DISCUSSION}

Tourism is an activity that influences positively the local economies. It increases the income of residents and decreases the unemployment, by offering employment to thousands of people (e.g., Fletcher, 1989; Comerio and Strozzi, 2019). It is observed that internationally there is a shift from mass tourism to alternative forms of tourism. Dance tourism constitutes such a form of tourism since it constitutes a category of cultural tourism. Through this, tourists have the opportunity to live an authentic experience and to meet the customs and the traditions of a place. On the other hand, national governments and local authorities employ cultural festivals and special events such as dance festivals as key elements within regional development strategies, since they provide opportunities for increased revenues, and investment in host regions (Getz, 2007; Van de Wagen, 2005; Waitt, 2008; Tuuri et al., 2012; Georgoula and Terkenlis 2018).

This research examined two dance tourists markets and several interesting findings emerged. Firstly, based on the common demographic characteristic of those markets (that is to say, gender, age, income, occupation, education, and marital status), it is observed that for dance tourism individuals aged mainly of 26-35 years old, followed below 25 years old and then individuals of 36-45 years old are interested in dance tourism. That is to say, the age criterion is individuals of middle and young age, who are interested to participate to dance activities during their trip. Regarding the gender, the majority of individuals who are interested in dance tourism are women, single, of high 
educational level, private-sector employees mainly, and of medium income. These results are partially in line with previous studies in the field (McCleary et al., 2005) where dance tourism participants tended to be middle aged, well educated, but married. Moreover, the results agree almost totally with Georgoula and Terkenli's research in Greece (2018) about two famous festivals. However, one of them was the Kalamata International Dance Festival (KIDF). In this research, the sample of the KIDF consisted of people aged $24-40$ years, and $76.2 \%$ female respondents. Nearly half of the respondents had a high educational profile, and most of the respondents were either self-employed (KIDF 35.7\%) or private-sector employees (KIDF 34.1\%).

Based on the two samples tourism behaviour, many elements were examined, such as the aim of their trip, the price and other elements which are concerned with the activities which they wish to be included in the tourism destination. From the similar results of the two market groups, it emerges that dance tourists realise these trips with the main aim to participate to dance events. This participation is mainly to dance at them or the combination of attending the events and their active participation (dancing) at them. These are more concerned with events that have to do with social events. According to results, the basic factor that encourages people to travel in order to take part in such events is escape and relaxation. This could be analysed psychologically, that is to say, that it is concerned with the everyday routine and the relaxation from the stress of everyday life. Regarding the activities that they wish to find at a destination, apart from dance events, they should be offered also opportunities to have fun, to go sightseeing at cultural attractions such as museums and to have options for entertainment. These should be offered with a good price-quality ratio.

In order to make dance tourism attractive to this type of tourists, an association should be created which will be in charge of its development. Based on the results of the present research, some significant suggestions for the development of dance tourism destinations evolved. Firstly, destinations should take advantage of dance events in order to attract tourists. Dance events should focus on the active participation of tourists in them. The events should be more in number during the entire year, so that they can give the opportunity to tourists to be entertained and have fun from them. However, more emphasis will be given from spring to autumn with the organisation of more outdoor dance performances, because visitors prefer that time period more for this type of tourism. Unique dance performances should be presented, designed with attention regarding some elements. Such elements which should be given emphasis in order to satisfy tourists are the following: there should be a rigid rhythm in music, live music, big stage for dance, unique atmosphere, the events should be held at locations that are accessible, the participants should be able to move freely on stage and there should be an area for non-smokers. Moreover, destination manages should take advantage of the plenty cultural associations and private dance schools in order to create a consistent programme with dance performances and events with long duration. In the context of the organisation of such dance events, local products of the area should be promoted as destination is a bundle of services and products (Zouni \& Kouremenos, 2008).

Without doubt, Patras region has prospects to develop dance tourism, so that it can be established as a dance destination in Greece and in overseas markets. What is needed to have a successful development of dance tourism is political will and right decisions from the responsible local association that are actively working in the sector of tourism. It is 
hoped that the results of the study will contribute to a deeper comprehension of the dance tourism market and be helpful to destinations and organisers of international dance events.

\section{RECOMMENDATION AND CONCLUSION}

The results of this study highlight the importance of evaluating festival attendants' profile characteristic and motives as a basis for more concerted and comprehensive marketing strategies, both at national and international levels. Such findings may play a significant role in having an impact on relevant authorities' decision-making, in developing successful strategic tourism planning and policy. Furthermore, they may encourage festival organizers to assess audience needs and improve the future organization and promotion of such events, towards a wider audience reach. This study may be considered as a first step towards understanding such target market characteristics and could also be undertaken at a larger scale, with the inclusion of a wider variety of socio-demographic groups (Georgoula \& Terkenli, 2018).

In this scope it would be beneficial to enlarge the present research setting to other travel behavioural and emotional characteristics and to widen the nationalities under study. For academia, this research might deepen the understanding of dance tourism travellers and its impact on destinations products formulation. For practitioners, this kind of approach might provide new and strategically important knowledge about future attendance in dance festivals events. Selective tourism marketing techniques are feasible only if dance tourists and their socio-demographic variables are clearly indicated since this allows tourism experts to 'develop a better understanding of distinct tourist characteristics and for developing marketing strategies' (Park, Yang, Lee, \& Stokowski, 2002, p. 55). The implementation of effective promotional and functional activities targeted at potential dance tourists requires a sound comprehension of this type of visitors.

Concluding, from the above research is observed that the cultural capital in regard to the dance that the area accumulated is significant and it can constitute the vehicle with which it will be developed in terms of tourism and will attract a significant number of tourists. The development of this multifaceted and complex tourism product will have multiple benefits for the local economy, the society and the culture and it will encourage the area to differentiate itself as a tourism destination regarding its competitors.

\section{References}

Comerio, N., \& Strozzi, F. (2019). Tourism and its economic impact: A literature review using bibliometric tools. Tourism Economics, 25(1), 109-131.

Crompton, J. L., \& McKay, S. L. (1997). Motives of visitors attending festival events. Annals of tourism research, 24, (2), 425-439

Cronin, M., \& O'Connor, B. (Eds.). (2003). Irish tourism: Image, culture and identity (Vol. 1). Channel View Publications. 
Tourism\&Heritage Journal / Vol.1 2019

Cuban Cultural Travel, 2019 http://cubanculturaltravel.com/about-us/ (accessed on 10 February 2019)

Daniel, Y. (1996). Tourism Dance Performances, authenticity and creativity. Annals of Tourism Research, 23, (4), 780-797

Filippou, F., Goulimaris, D., Mihaltsi, M., \& Genti, M. (2010). Dance and Cultural Tourism: The effect of demographic characteristics on foreigners' participation in traditional Greek Dancing courses. Studies in Physical Culture \& Tourism, 17(1), 63-71.

Fletcher, J. E. (1989). Input-output analysis and tourism impact studies. Annals of tourism research, 16(4), 514-529.

Foley, C. E. (2018). International folk dance festivals in Ireland: a comparative analysis of Oireachtas Rince na Cruinne and Damhsafest, Cork International Folk-Dance Festival. Ege University Publications, State Turkish Music Conservatory, Publication No: 16.

Georgoula, V., \& Terkenli, T. S. (2018). Tourism Impacts of International Arts Festivals in Greece. The Cases of the Kalamata Dance Festival and Drama Short Film Festival. Journal of Tourism and Hospitality Management, 6, (4), 187-200

Getz, D. (1991). Festivals, Special Events, and Tourism. New York: Van Nostrand Reinhold.

Kassing, G. (2007). History of dance: an interactive arts approach. United States: Human Kinetics.

Kringelbach N. H., Skinner J., (2012). Dancing cultures: globalization, tourism and identity in the anthropology of dance, eBook: Berghahn Books

Lee, J., Kyle, G., \& Scott, D. (2012). The mediating effect of place attachment on the relationship between festival satisfaction and loyalty to the festival hosting destination. Journal of Travel Research, 51, (6), 754-767

Lee, Y. K., Lee, C. K., Lee, S. K., \& Babin, B. J. (2008). Festivalscapes and patrons' emotions, satisfaction, and loyalty. Journal of business research, 61(1), 56-64.

Little, N., Burger, B., \& Croucher, S. M. (2018). EDM and ecstasy: The lived experiences of electronic dance music festival attendees. Journal of New Music Research, 47, (1), 78-95

McCleary, K. W., Weaver, P. A., \& Meng, F. (2005). Dance as a tourism activity: Demographics, demand characteristics, motivation, and segmentation. Tourism Analysis, 10, (3), 277-290

Nicholson, R., \& Pearce, D. G. (2001). Why do people attend events: A comparative analysis of visitor motivations at four South Island events. Journal of Travel Research, 39, 449-460

Park, M., Yang, X., Lee, B., \& Stokowski, P.A. (2002). Segmenting casino gamblers by involvement profiles: a Colorado example. Tourism Management, 23(2), 55-65

Prantzidis, I. (2005). Dance in Greek tradition and it's education, Aeginiou Publicing (in Greek)

Schneider, I. E., \& Backman, S. J. (1996). Cross-cultural equivalence of festival motivations: A study in Jordan. Festival Management and Event Tourism, 4, (3-4), 139-144 
Scott, D. (1995). A comparison of visitors' motivations to attend three urban festivals. Festival Management and Event Tourism, 3, (3), 121-128

Skoultsos, S. (2014). Events as Special Interest Tourism and as Leisure Time Activity: Market Characteristics and Management, Aegean University (in Greek)

Suharji. (2017). Bedhaya Bedhah Madiun dance: As a tourism superior asset in puro Mangkunagaran. Harmonia: Journal of Arts Research And Education, 17, (2), 190-198

Težak, A., Saftić, D., \& Šergo, Z. (2011). Relationship between cultural/artistic events visitation and other activity-based tourism segments. Ekonomska misao i praksa, (1), 121-135.

Thimm, T. (2014). Dance Tourism Business Models in Seville and Buenos Aires: dimensions of meaning of intangible cultural assets in destination management. Via. Tourism Review, (6).

Tuuri, H., Rumpunen, S., Kortesluoma, A., \& Katajavirta, M. (2012). Summer events of 2012 in Southern Ostrobothnia, audience profiles, visitor satisfaction and regional economic impacts. Seinäjoki: Seinäjoen ammattikorkeakoulu, Markkinatutkimuspalvelut. Retrieved from https://storage.googleapis.com/seamk-production/2018/01/kesatapahtumat2012.pdf

UNESCO. Records of General Conference, Paris, 29 September to 17 October 2003; Volume 1. Resolutions. 32nd Session. Available online: http://unesdoc.unesco.org/images/0013/001331/133171e.pdf (accessed on 22 January 2019).

Van de Wagen, L. (2005). Event management: For tourism, cultural, business and sporting events (2nd ed.). Frenchs Fores, N.S.W.: Pearson Education.

Waitt, G. (2008). Urban festivals: Geographies of hype, helplessness and hope. Geography Compass, 2(2), 513-537.

Wall, G., \& Xie, P. F. (2005). Authenticating ethnic tourism: Li dancers' perspectives. Asia Pacific Journal of Tourism Research, 10, (1), 1-21

World Tourism Organization (2016), UNWTO/UNESCO World Conference on Tourism and Culture:Building a New Partnership Siem Reap, Cambodia, 4-6 February, Published by the World Tourism Organization (UNWTO). Available online: https://www.eunwto.org/doi/pdf/10.18111/9789284417360 (accessed on 10 February 2019)

Zouni, G., \& Kouremenos, A. (2008). Do tourism providers know their visitors? An investigation of tourism experience at a destination. Tourism and Hospitality Research, 8(4), 282-297. 